\title{
気管浸潤を来たした甲状腺扁平上皮癌の一例
}

\author{
百 田 統 洋，梅 崎 俊 郎 \\ 高木誠治, 進武幹
}

\section{A Case of Squamous Cell Carcinoma of the Thyroid Gland Invasive to the Trachea Reconstructed with Nasal Septum}

\author{
Tsuguhiro Momota, M.D., Toshiro Umezaki, M.D., Seiji Takagi, M.D., \\ and Takemoto Shin, M.D. \\ Department of Otolaryngology, Head and Neck Surgery, Saga Medical School, Saga
}

The case of a 75-year-old man with squamous cell carcinoma of the thyroid gland invasive to the cervical trachea was reported. Squamous cell carcinoma originating in the thyroid gland is uncommon and is reported to have a poor prognosis. The patient came to our department with complaints of a fever of unknown origin and a large mass in the left anterior neck. He was diagnosed as having squamous cell carcinoma of the thyroid gland from the specimen biopsied through a needle, and it was suspected that the tumor had invaded the tracheal wall. He underwent a radical resection of the thyroid tumor concomitant with a left radical neck dissection and a oval-shape resection of the tracheal wall. Secondary reconstruction of the trachea was performed with a skin flap in which the nasal septal cartilage was implanted. A satisfactory postoperative status was obtained.

\footnotetext{
Key words : thyroid carcinoma, squamous cell carcinoma, tracheoplasty, nasal septal cartilage
}

\section{I .はじめに}

甲状腺原発の扁平上皮癌は稀であり，急速進 行性の発育を示し，しかも他の頭頸部癌とは異 なり放射線照射や化学療法に抵抗することが多

く，未分化癌とともに予後不良の癌とされてい る。したがって根治的手術のためには喉頭や気 管, 食道の合併切除を余儀なくされる場合も多 (1)。

最近われわれは，気管壁に浸潤した甲状腺扁 平上皮癌の 1 例を経験し, 頸部気管の合併切除

佐賀医科大学耳鼻咽喉科学教室

別刷請求：干849 佐賀県佐賀市鍋島5-1-1 佐賀医科大学耳鼻咽喉科学教室 百田統洋

投稿受付：1993年 7 月26日
を含めた根治的手術後，鼻中隔軟骨を用いた気 管形成により良好な結果を得たので報告する。

\section{II . 症例}

症 例：Y.K., 75歳男性

主 訴：発熱抢よび左前頸部腫瘤

既往歴・家族歴：特記すべき事項なし

現病歴：1991年 5 月下旬より $37^{\circ} \mathrm{C}$ 台の発熱が 持続し，左前頸部に母指頭大の無痛性の腫瘤を 自覚した。腫瘤は急速に増大し発熱も続くた め, 精査目的にて同年 6 月 28 日当院内科入院と なった。頸部の CTscan および甲状腺シンチグ ラフィー等の検査により甲状腺腫瘍を疑われ， 針生検にて扁平上皮癌と診断され, 手術目的に て同年 7 月 16 日当科転科となった。

入院時理学所見: 甲状腺左葉に一致して, 
日気食会報，45（3），1994

$7.5 \times 5.5 \mathrm{~cm}$ の弾性硬の無痛性の腫瘤を触知し た（図 1 )。深部組織との癒着は認められるも， 皮膚との癒着は認められず。頸部リンパ節は触 知せず，声帯の可動性も良好であった。また， 気管の内視鏡検査では，腫瘤による気管壁の圧 排は認められるものの内腔への突出，浸潤はな かった。

血液検査所見：白血球数 $13,300 / \mu 1$, 赤沈值 $43.3 \mathrm{~mm} / 1$ 時間, CRP7.5 と著明な炎症所見を 呈していた。甲状腺機能はすべて正常範囲内で あったが, 腫瘍マーカーである血中 CEA は6.2 $\mathrm{ng} / \mathrm{ml}, \mathrm{SCC}$ 抗原は $4.3 \mathrm{ng} / \mathrm{ml}$ と上昇していた。

画像所見：頸部 CT 像では, 甲状腺左葉に 7 $\times 6 \mathrm{~cm}$ の充実性の腫瘍性病変が認められ, 内 部 density は不均一で，一部に石灰化も認めら れた。また頸部気管は右方へ圧排されており， 腫瘍と気管壁や周囲組織との境界も不明瞭で被

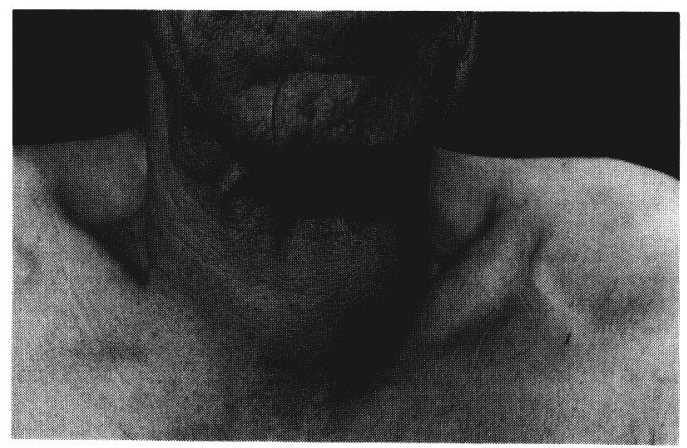

図 1 頸部局所所見（術前）

前頸部に巨大な腫瘤を触知した。

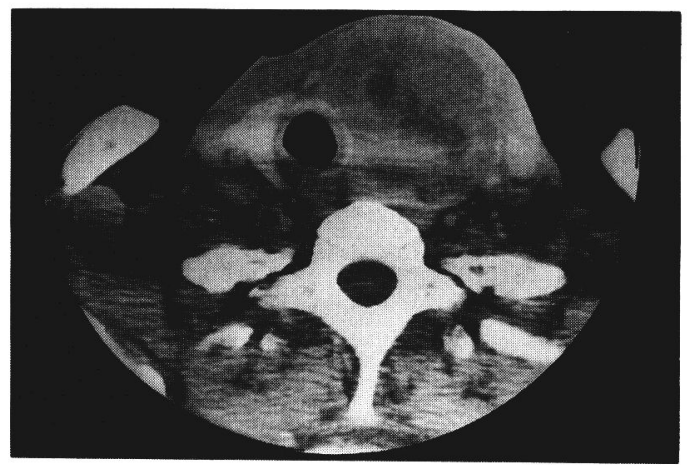

図 2 頸部 CT 所見

甲状腺左葉を中心に内部不均一な巨大な腫瘍性病変 を認め, 一部石扊化も認める。

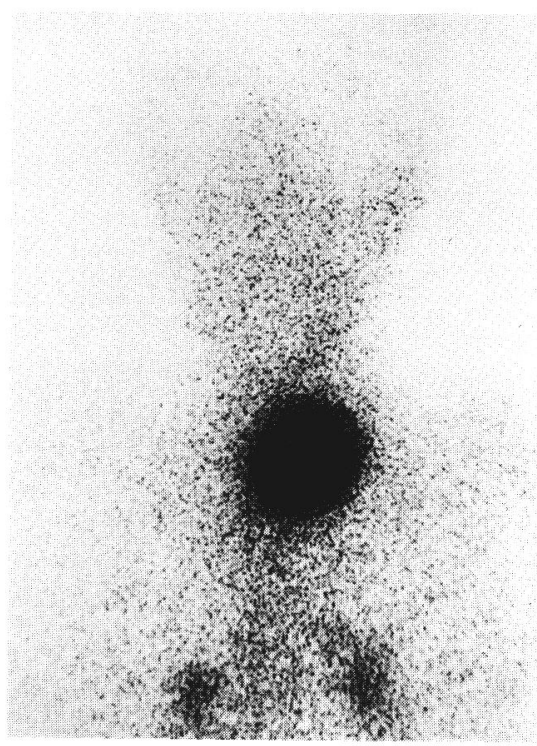

図 $3 \mathrm{Ga}$ シンチ所見

腫瘍に一致して高い集積が認められる。
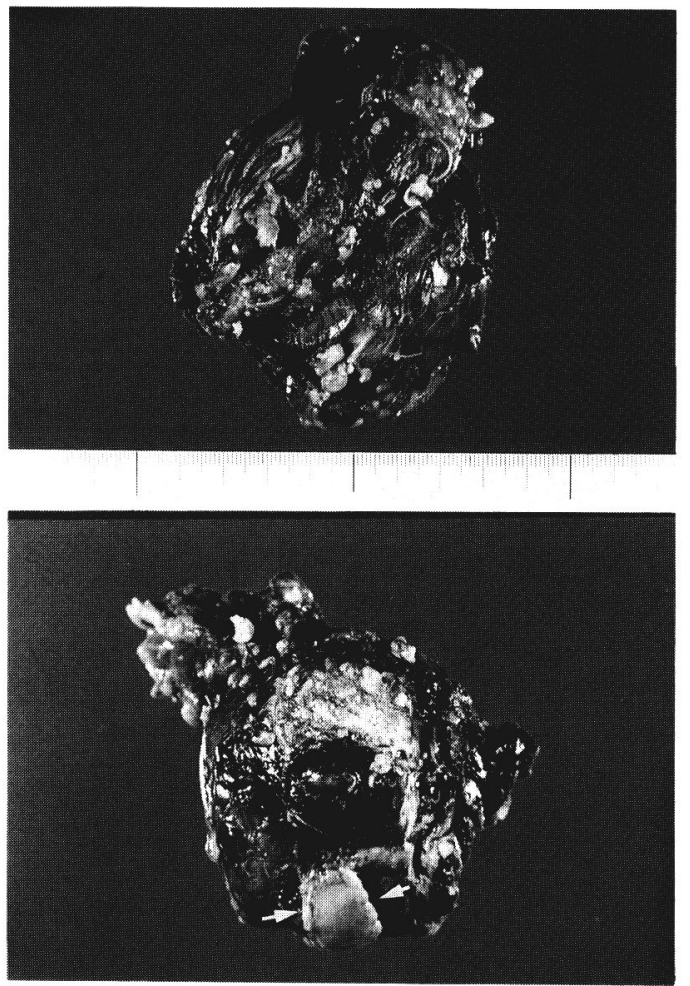

図 4 摘出腫瘍

割面では内部に出血壊死，石灰化が認められた。腫 瘍裏面には合併切除した気管壁（下図，矢印) が付 着している。 
膜外進展が疑われた（図 2 )。Ga シンチでは腫 瘍に一致して高い集積が認められ(図 3 )，甲状 腺 T1 シンチでも同様に異常集積を認めた。

以上より，甲状腺扁平上皮癌 $\mathrm{T} 4 \mathrm{~N} 0 \mathrm{M} 0$ と診 断し，1991年 7 月19日全麻下に甲状腺亜全摘と 左頸部根治的郭清術を施行した。

手術および治療経過：腫場は左葉を中心に発 育し，弾性硬で周囲組織との癒着は強く，境界 不明瞭であった。また腫瘍は後面において一部

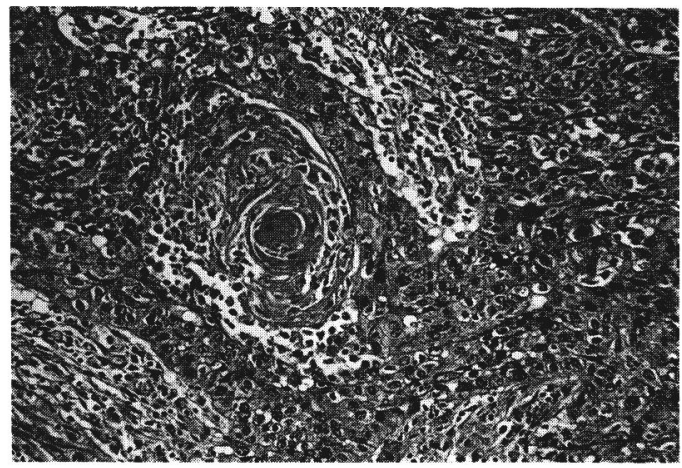

図 5 病理組織像（HE 染色）

角化傾向を伴う異型上皮の増殖が認められる。
気管に浸潤していたため，気管前壁を含めて， 頸部郭清組織とともに en bloc に摘出した。切 除した気管壁の大きさは $2.7 \times 1.8 \mathrm{~cm}$ で，皮膚 面に開空する形で気管口を作製し 1 次手術を終 了した。摘出された腫陽の大きさは $8 \times 6 \times 6$ cm で，重量は $120 \mathrm{~g}$ であった（図 4)，

病理組織所見（図 5 ）は，角化傾向を伴う異 型上皮細胞が不規則に増殖浸潤しており，中分 化型扁平上皮癌と診断された。また，気管上皮 との腫瘍の連続性はなく，甲状腺原発であるこ

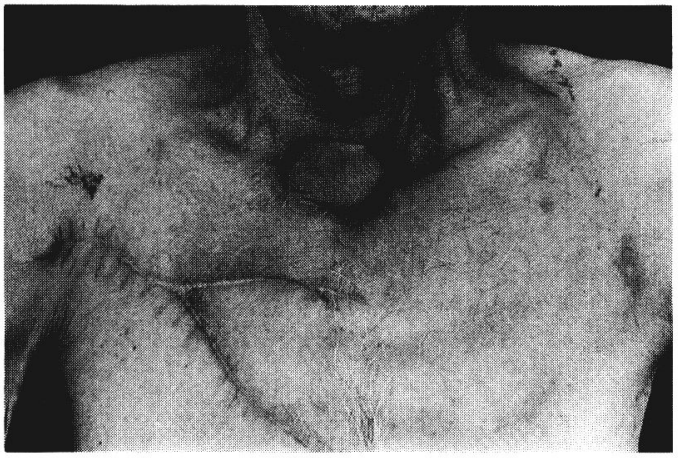

図 7 気管形成終了後（約 1 力月）の前頸部の状態
1

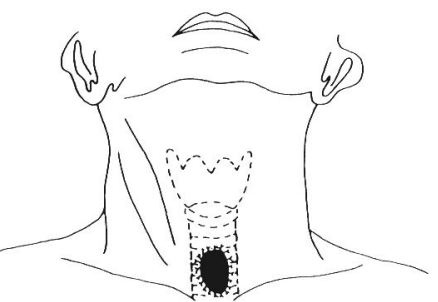

3

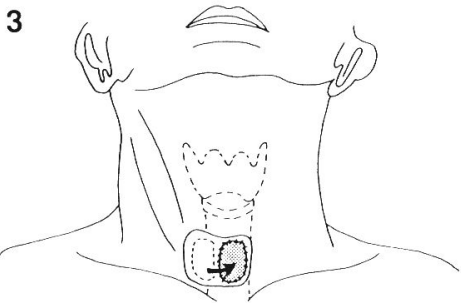

2

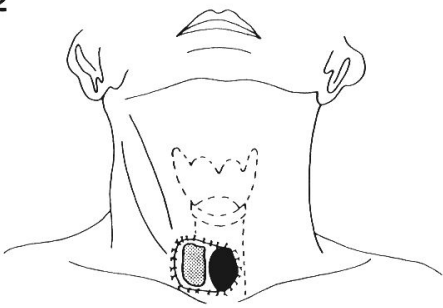

4

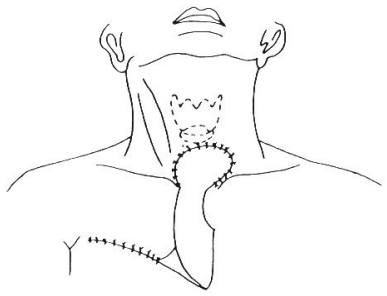

図6 気管再建の術式

1 : 気管口は皮膚面に開空されている。2：気管開密部外側に皮切を加え， 採取した鼻中隔軟骨を皮下に移植する。3 : 生着した軟骨を含む door 状 の皮弁を反転縫合し，気管前壁を形成する。4：軟骨皮弁反転後の皮膚欠 損部を D-P 皮弁にて被覆する。 
とが判明した。

腫瘍摘出後は体温もすみやかに正常化し, 血 液検査上も炎症反応は消退した。

気管開空部再建のため，同年 8 月 23 日鼻中隔 軟骨を採取し，気管開空の大きさに合わせてト リミングし，気管開空部右側の皮下に移植した (図 6-2)。約 3 週間軟骨生着を待ち, 鼻中隔軟 骨移植部位を開空部の大きさに合わせてデザイ ンした door flap を反転縫合し(図 6-3), それ によって生じた皮膚欠損部は右 D-P 皮弁によ り被覆した(図 6-4)。さらに 3 週後 D-P 皮弁 を切離し気管形成術を終了した（図 7 )。

術後は皮弁の生着もよく, 軽度の左反回神経 麻痺を残すのみで気管の狭窄を来すこともな く，音声も良好である。また根治術後約 2 年現 在で，局所再発や遠隔転移の徴候もなく経過良 好である。

\section{III. 考 察}

冒頭でも述べたように，甲状腺原発扁平上皮 癌は稀であり, 諸家の報告では本邦・欧米とも 甲状腺癌の $1 \%$ 前後とされている ${ }^{2 \sim 4)}$ 。甲状腺に 扁平上皮癌の発生する起源に関しては，胎生期 の遺残・迷芽より発生 ${ }^{5,6)}$, 濾胞上皮の扁平上皮 化生よりの癌化 ${ }^{2,6 \sim 8)}$, 腺癌からの直接移行 ${ }^{9,10)}$ の 3 説があるが，今のところ決定的なものはな w。

甲状腺扁平上皮癌の臨床的特徵としては，硬 く山凸不整で，周囲組織との癒着が強く可動性 に乏しい腫瘤で，発生に性差はなく，他の頭頸 部の扁平上皮癌と年齢分布においても大差はな ( ${ }^{3,4,9)}$ 。しかしながら本腫瘍の発育は急速で, 周 囲組織への浸潤も強いため, 嗄声, 嬩下障害や 呼吸困難を伴って来院する例が多い4,8)。予後は 極めて悪く，報告例の多くは発症後ほぼ 1 年以 内に局所再発や遠隔転移にて死亡してい る $^{3,9,10)}$ 。

特筆すべきことは，本症例にもみられたよう に，病勢に応じて発熱，赤沈穴進，白血球増多 などの炎症所見を呈することである ${ }^{3,10)}$ 。その理 由については明らかにされていないが，予後と の相関でみると, $8,000 / \mu 1$ 以上の白血球増多を 示した症例のほとんどが 1 年末満に死亡してい るという報告 ${ }^{11)} も$ あ，本疾患の腫瘍活性と抗
原呈示性の関連など，今後検討されるべき課題 である。

治療に関しては，放射線治療あるいは化学療 法単独では十分な効果が得られない2,3) ため, 可 及的早期の根治手術が望まれる。近年，甲状腺 進行癌に対しては，喉頭や気管，食道の合併切 除も含めた拡大手術が行われるようにな $\eta^{1,12,13)}$ ，本疾患の予後の向上も期待できる。そ の際の気管合併切除に対しては，気管端々吻合 あるいは輪状軟骨・気管吻合の術式が多く採ら れているが14,15)，今回われわれの行った鼻中隔 軟骨を用いた気管形成術は有用な術式であると 考えられる。

この術式の長所は, 自家組織である鼻中隔軟 骨は異物反応がなく生着がよいことであるが， 比較的小さな気管欠損にしか適用できず，また 段階的手術であるので，治療に要する期間が長 いという久点もある。また，気管内腔に反転し た皮膚面に落屑が付着し, 喀痰の排泄を阻害す ることも懸念されるが，これに対して鼻中隔粘 膜軟骨弁を用いて気管壁を再建する術式16 18) も報告されている。今後さらに気管の再建法に ついても検討する必要があると思われる。

以上，甲状腺扁平上皮癌の 1 例を経験し，気 管合併切除後の再建についても考察し報告し た。

本論文の要旨は第 2 回日本頭頸部外科学会（1992 年1月24日，福岡）にて口演した。

\section{文献}

1) 吉積 隆, 海老原敏, 平野浩一・他：甲状腺進 行癌の手術一気管喉頭合併切除を中心に一. 頭 頸部外科， 2 : 69-74, 1992.

2 ) Goldman, R.L. : Primary squamous cell carcinoma of the thyroid grand: Report of a case and review of the literature. Am. Surg., $30: 247-252,1964$.

3 ）宮川 信，関 龍幸，佐藤起夫・他：甲状腺原 発の扁平上皮癌. 癌の臨床，19：193-200, 1973.

4 ）北村博之, 斉藤春雄, 東辻英郎：甲状腺原発扁 平上皮癌. 耳鼻臨床，69：1697-1703, 1976.

5 ) Smith, L.W., Pool, E.H., and Olcott, C.T. : Malignant disease of the thyroid grand: A clinico-pathological analysis of 54 cases of thyroid malignancy. Am. J. Cancer, $20: 1-32$, 1934.

6 ）渡辺元治：甲状腺扁平上皮癌の二例. 信州医誌， 
8: 798-801, 1959.

7 ) Saxén, E. : Squamous metaplasia in the thyroid gland and histogenesis of epidermoid carcinoma of the thyroid. Acta Pathol. Micro. Scand., $28: 55-60,1951$.

8 ）真鍋重夫, 高井孝二, 斉藤公司 - 他：甲状腺原 発扁平上皮癌の 2 症例。ホルモンと臨床，28： 1031-1036, 1980.

9 ) 黒田建彰, 東家倫夫, 佐藤武男: 甲状腺原発扁 平上皮癌の一症例.耳鼻臨床, 71, 269-274, 1978.

10）仙波 治, 川堀眞一, 奥田 稔: 甲状腺扁平上 皮癌の病理一光顕扔よび電顕的観察—. 癌の臨 床，26：483-489, 1980 .

11）岸本誠司，田島和幸，園部 宏：甲状腺扁平上 皮癌および腺扁平上皮癌。癌の臨床，33： 1353-1360, 1987.

12）松浦秀博：甲状腺分化癌の手術はどこまで進歩
したか.耳鼻，36：859-866, 1990.

13）佐藤武男，吉野邦俊，馬谷克則・他：甲状腺進 行癌の拡大手術について。耳鼻, 36：897-903, 1990.

14）前田昌純，宮内 昭，隅 寛二・他：甲状腺癌 に対する気管形成術。日胸外会誌, $30 ： 574-576$, 1982.

15）池田高明：気管形成術を行った甲状腺癌の検 討. 胸部外科, $40 ： 96-101,1987$.

16) Krizek, T.J., and Kirchner, J.A. : Tracheal reconstruction with an autogenous mucochondrial graft. Plast \& Reconstr. Surg., 50 : 123-130, 1972.

17）奥田 稔, 海野徳二：鼻中隔を利用した一次的 頸部気管形成例. 耳喉，45：439-443, 1973.

18）進 武幹：気管狭窄の治療.耳鼻臨床，74： 891-895, 1981. 